\title{
УАK 556.5
}

\section{МИКРОЭЛЕМЕНТЫ В ВОДЕ ПРИТОКОВ НИЖНЕ-БУРЕЙСКОГО ВОДОХРАНИЛИЩА}

\section{(C) 2016 г. Н.М. Шестеркина, В.П. Шестеркин}

ФГБУН «Институт водных и экологических проблем Аальневосточного отделения Российской академии наук», г. Хабаровск, Россия

Кмючевые слова: Нижне-Бурейское водохранилище, р. Бурея, малые реки, химический состав воды, микроэлементы, сезонная и многолетняя изменчивость, воАные экосистемы.

Реализация масштабных проектов по строительству и эксп уатации гидроузмов является серьезным фактором вмешательства в функционирование водных экосистем. По результатам мониторинга речных воА в зоне строящейся НижнеБурейской ГЭС в 2011-2014 гг. Аана характеристика химического состава воА р. Бурея и ее притоков, показаны значительные вариации физико-химических характеристик воА малых рек. Выявлена сезонная и многолетняя Аинамика содер-

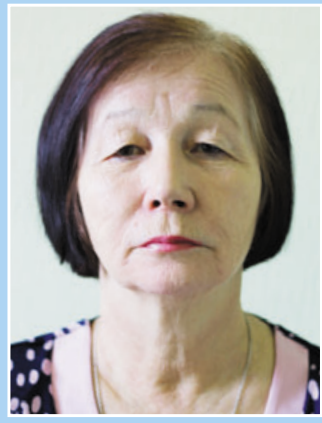

Н.М. Шестеркина

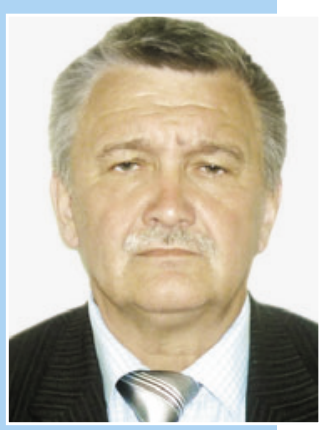

В.П. Шестеркин жания растворенных форм микроэлементов. Установлены повышенные концентрации железа, марганца, меАи, ртути, значительные их вариации, связанные с природными особенностями территории.

Воды малых рек, Аренирующих преимущественно эффузивные породы, характеризуются повышенными концентрациями железа и марганца, осадочные породы - алюминия. Характер сезонной и многолетней изменчивости содержания растворенных форм микроэлементов разнообразен, в большой степени определяется гиАрологическим фактором. В многоводном 2013 г. отмечено существенное повышение стока меАи и бария во всех притоках, алюминия - в р. Бурея, незначительное увеличение содержания железа отмечалось во всех притоках, каАмия - в отдельных водотоках, Аля остальных микроэлементов выраженного увеличения содержания не наблюАалось.

Створ строящейся плотины Нижне-Бурейской ГЭС расположен в 89 км от устья р. Буреи, площаАь водосбора в створе ГЭС состав яет 67400 км², площадь акватории - 153,3 км², наибольшая ширина водохранилища 5 км, среАняя глубина - 13 м. Верхняя часть бассейна находится в зоне многолетней мерзцоты, в южной части мерзцота островная. 
По водному режиму реки бассейна Буреи относятся к Аальневосточному типу. Основным источником их питания явАяются АожАи, АОАя которых в среАнем 50-70 \% от общего годового стока. Снеговое питание составАяет 10-20 \%, подземное $10-30 \%$.

Заполнение можа Нижне-Бурейского водохранимища запланировано на 2016 г. Основным его притоком является р. Бурея, сток которой зарегулирован в 2003 г. Сооружение плотины Бурейской ГЭС привело к значительному изменению гиАрологического режима р. Буреи в нижнем течении. Существенно выросли расходы воды в зимнюю межень, в декабре-марте 2011-2014 гг. они изменялись от 682 до 757 м³/с, в среАнем составив $723 \mathrm{~m}^{3} / \mathrm{c}$. В период открытого русла расходы воды варьировали в преАелах 666-1432 м³ с, максимальные значения отмечались в многоводном 2013 г. Остальные притоки по воАности на Ава порядка ниже р. Буреи, характеризуются малой Алиной (< 40 км), максимальная площадь водосбора 440 км $^{2}$ (р. Аея). Суммарный среАнегодовой сток этих рек не превышает $9 \mathrm{~m}^{3} / \mathrm{c}$ $\left(4,14 \mathrm{~m}^{3} / \mathrm{c}\right.$ - p. Аея, 2,69 м³/c - p. Синель) [1]. Химический состав воА притоков формируется на водосборах, сложенных осадочными и магматическими породами, в период исследований - в условиях значительных колебаний водного стока за счет больших разАичий в количестве атмосферных осадков (по данным Росгидромета в г. Благовещенске в мае-сентябре 2011 г. выпало 499 мм, 2012 г. - 380, 2013 г. - 772, 2014 г. - 312 мм осадков).

Реализация масштабных проектов по строительству и экспцуатации гиАроузлов, несомненно, может стать серьезным фактором вмешательства в функционирование водных экосистем и привести к изменению качества речных вод. Поэтому кроме технических мероприятий, направленных на снижение нежелательных послеАствий строительства, возникает необхоАимость ведения мониторинга поверхностных воА в зоне вАияния строящихся гиАроузлов. В этом плане актуальны вопросы гиАрохимического мониторинга в зоне функционирующего крупного Бурейского гиАроузла и строящейся новой Нижне-Бурейской ГЭС. Наиболее Аетально в воде притоков будущего водохранимища изучено содержание главных ионов, биогенных и органических веществ [2,3], в меньшей степени - микроэлементов $[4,5]$. Представленная работа восполняет этот пробел.

\section{ОБЪЕКТЫ И МЕТОАЫ}

Исследования проводили в 2011 г. в июле и октябре, в 2012-2014 гг. четыре раза, с мая по ноябрь. Пробы воды отбирали на р. Бурея: у пос. Тацакан, на трех станциях равномерно распределенных по ширине русла выше и на оАной станции на сереАине ниже плотины Нижне-Бурейской ГЭС; на правобережных малых реках. В октябре 2014 г. исследовали мевобережные мамые реки (рис. 1).

ВоАное хозяйство России № 3, 2016 г. 
Период исслеАований в гиАрологическом отношении охватывал весеннее половодье, метние паводки с переходом к глубокой осенней межени. Пробы воды отбира ии споверхности, фильтровали через мембранные фильтры сразмером пор 0,45 мкм, что позволяло опреАелять растворенные формы микроэлементов. Анализ проводици методом масс-спектрометрии с индуктивносвязанной плазмой на приборе ICP-MS Agilent $7500 \mathrm{cx}$ в ЦКП АВО РАН «Межрегиональный центр экомогического мониторинга гиАроузАов».

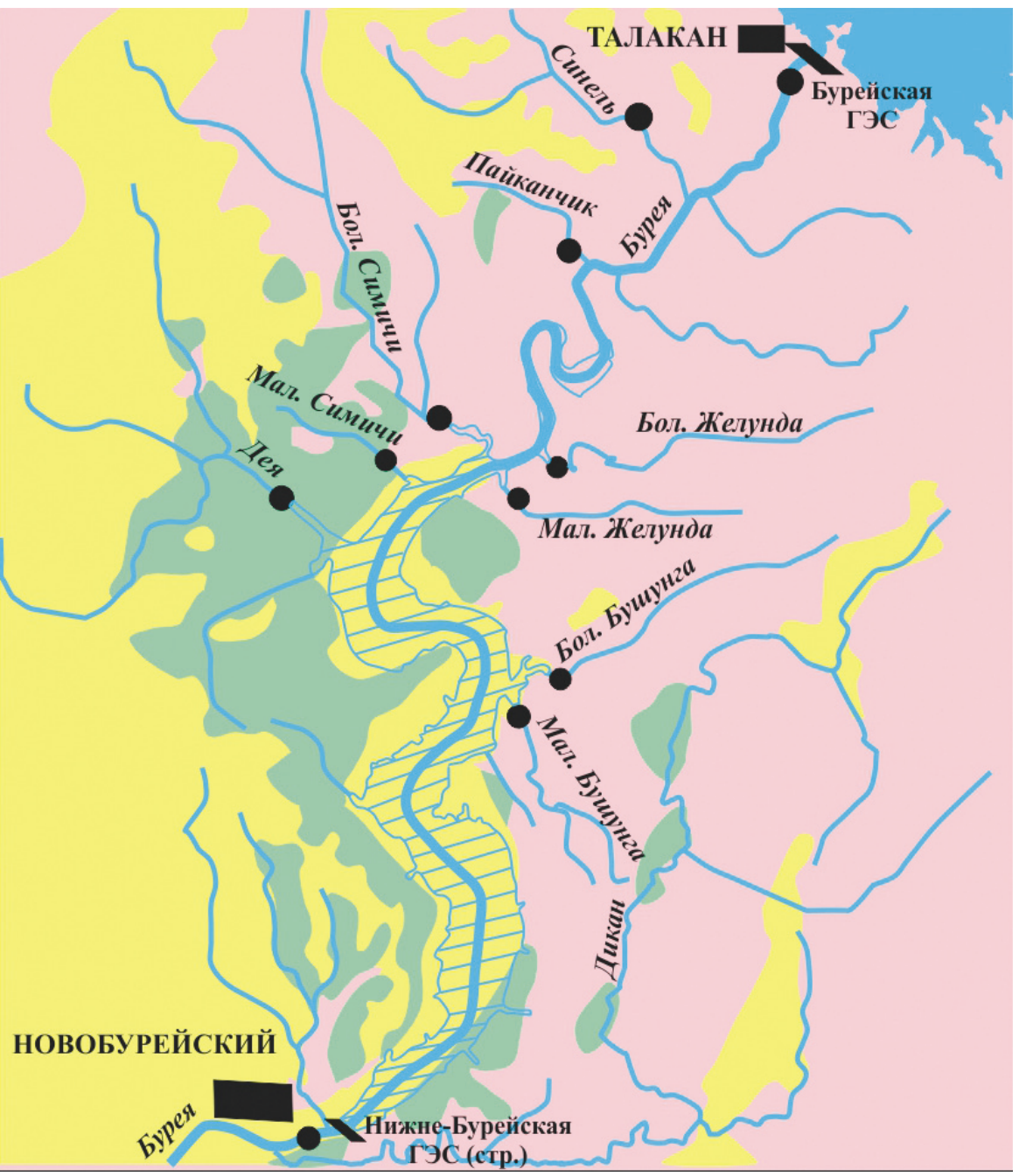

Рис. 1. Схема района исследований.

Водное хозяйство России № 3, 2016 г. ВОДНОЕ ХОВЯЙТВО РОССИИ 
При оценке степени загрязненности воА использовали значения преАельно Аопустимых концентраций (ПАК) вреАных веществ Аля водных объектов рыбохозяйственного значения, принятые Аля Российской Федерации [6].

\section{РЕЗУАЬТАТЫ ИССАЕАОВАНИЙ}

По химическому составу речные воды относятся к гиАрокарбонатному кмассу, группе кальция, первому типу [7], характеризуются удовлетворительным содержанием кислорода. Значения $\mathrm{pH}$ варьируют в широких пределах от 5,97 до 8,10. В среАнем кислотность воды р. Буреи ближе к нейтральной $(6,75)$, притоков - сАвинута в щелочную область (табл. 1).

Минерализация воды малых рек, за искмючением рек Пайканчик и Мамые Симичи, менее 65 мг/Ам³. Более высокая минерализация воА р. Пайканчик (табл. 1) может быть вызвана проявлениями $\mathrm{Au}, \mathrm{Ag}, \mathrm{Sn}$ на водосбоpe [8], a p. Малые Симичи, выделяющейся повышенными значениями рН и концентрациями гиАрокарбонатов натрия, кальция и магния [2], - разгрузкой артезианских воА. Пониженные значения наблюАались в условиях высокой водности в 2013 г. В воде р. Буреи минерализация воды не превышала $38 \mathrm{Mr} / \mathrm{AM}^{3}$.

Содержание взвешенных веществ изменяется от $<3$ Ао 36,0 мг/Ам ${ }^{3}$. Наибольшие значения фиксировались при высоких уровнях воды, наименьшие - в межень. В воде р. Буреи содержание взвешенных веществ, в основном, ниже 3 мг/Ам ${ }^{3}$, более высокие значения отмечались в 2013 г. при сбросах воды Бурейской ГЭС.

Заболоченность водосборов малых рек обусловливает в половодье и во время паводков повышенные значения цветности воА, ХПК и перманганатной окисляемости. В воде малых рек содержание трудноокисляемых органических веществ (по ХПК) в среАнем состав яет 18 мг О/Ам³ ${ }^{3}$ в р. Буреи 24 мг О/Ам ${ }^{3}$ (табл. 1) Наибольшие значения отмечены в октябре 2012 г., июле 2013 г. при сбросах воды [3].

Исследуемые реки не испытывают интенсивной антропогенной нагрузки, поэтому микроэлементный состав их воА опреАеляется, главным образом, $и$ иологией Аренируемых пороА. Микроэлементы характеризуются относительно невысоким содержанием, чаще всего не превышающим значений ПАК и среАнемировые показатели их содержания в речных водах $[9,10]$. Искиючение составляют $\mathrm{Mn}, \mathrm{Fe}, \mathrm{Cu}, \mathrm{Zn}, \mathrm{Hg}$, еАинично Ва (табл. 2-4).

Известно, что существенная часть всех транспортируемых речной сетью метал ов связана с взвешенными веществами. Распределение микроэлементов среди растворенной и взвешенной форм зависит от множества факторов. ОАнако наибольший эффект оказывают природа взвешенных веществ, компонентный состав и содержание в воде органических веществ.

ВоАное хозяйство России № 3, 2016 г. 
Таблица 1. Показатели качества вод притоков Нижне-Бурейского водохранилища

\begin{tabular}{|c|c|c|c|c|c|c|}
\hline $\begin{array}{c}\text { Река, число } \\
\text { проб }\end{array}$ & $\begin{array}{c}\mathrm{pH}, \\
\text { eA. } \mathrm{pH}\end{array}$ & $\begin{array}{c}\text { Минерами- } \\
\text { зация, } \\
\text { мг/АM }\end{array}$ & $\begin{array}{c}\mathrm{XПК,} \\
\mathrm{M \Gamma} \mathrm{O} / \mathrm{AM}^{3}\end{array}$ & $\begin{array}{c}\text { ПО, } \\
\mathrm{мг} \mathrm{O} / \mathrm{AM}^{3}\end{array}$ & $\begin{array}{c}\text { Цветность, } \\
\text { граА }\end{array}$ & $\begin{array}{c}\text { Взвешенные } \\
\text { вещества, } \\
\text { мг/Ам }\end{array}$ \\
\hline $\begin{array}{l}\text { Бурея, } \\
\text { пос. Талакан, } \\
n=14\end{array}$ & $\frac{6,72 \pm 0,27}{6,20-7,17}$ & $\frac{31,0 \pm 3,4}{27,5-37,0}$ & $\frac{25 \pm 4}{18-31}$ & $\frac{13,3 \pm 2,6}{9,0-17,9}$ & $\frac{70 \pm 15}{50-100}$ & $\begin{array}{r}\frac{3,0 \pm 3,6}{<3,0-14,5}\end{array}$ \\
\hline $\begin{array}{l}\text { Бурея, } \\
\text { выше НБГЭС, } \\
n=36\end{array}$ & $\frac{6,70 \pm 0,33}{5,97-7,19}$ & $\frac{31,4 \pm 3,3}{24,4-38,0}$ & $\frac{23 \pm 9}{12-56}$ & $\frac{13,9 \pm 3,4}{9,6-26,7}$ & $\frac{70 \pm 17}{46-100}$ & $\frac{<3,0 \pm 2,4}{<3,0-15,6}$ \\
\hline $\begin{array}{l}\text { Бурея, } \\
\text { ниже НБГЭС, } \\
n=14\end{array}$ & $\frac{6,83 \pm 0,28}{6,40-7,20}$ & $\frac{31,7 \pm 2,7}{26,4-35,0}$ & $\frac{23 \pm 8}{14-38}$ & $\frac{12,8 \pm 2,6}{9,7-17,1}$ & $\frac{68 \pm 17}{45-100}$ & 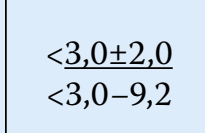 \\
\hline $\begin{array}{l}\text { Синемь, } \\
n=14\end{array}$ & $\frac{7,11 \pm 0,31}{6,56-7,80}$ & $\frac{38,2 \pm 10,0}{22,3-54,4}$ & $\frac{21 \pm 7}{12-40}$ & $\frac{11,3 \pm 5,0}{4,7-18,6}$ & $\frac{51 \pm 24}{14-85}$ & $\begin{array}{c}\frac{7,6 \pm 2,9}{<3,0-17,3}\end{array}$ \\
\hline $\begin{array}{l}\text { Бомьшие } \\
\text { Симичи, } \\
n=14\end{array}$ & $\frac{7,34 \pm 0,28}{6,93-8,00}$ & $\frac{49,2 \pm 10,8}{29,1-65,0}$ & $\frac{16 \pm 6}{<5-26}$ & $\frac{8,0 \pm 3,0}{3,7-13,0}$ & $\frac{30 \pm 15}{10-55}$ & $\frac{11,1 \pm 8,8}{<3,0-36,0}$ \\
\hline $\begin{array}{l}\text { Мамые } \\
\text { Симичи, } \\
n=14\end{array}$ & $\frac{7,32 \pm 0,44}{6,57-8,10}$ & $\frac{129,7 \pm 59,5}{40,8-230,3}$ & $\frac{14 \pm 6}{<5-22}$ & $\frac{7,2 \pm 3,1}{3,0-13,1}$ & $\frac{28 \pm 14}{5-57}$ & $\frac{3,9 \pm 2,1}{<3,0-8,0}$ \\
\hline $\begin{array}{l}\text { Пайканчик, } \\
n=14\end{array}$ & $\frac{7,21 \pm 0,15}{6,95-7,48}$ & $\frac{57,8 \pm 21,4}{30,3-104,0}$ & $\frac{17 \pm 9}{8-44}$ & $\frac{8,0 \pm 3,7}{4,0-16,8}$ & $\frac{47 \pm 63}{14-260}$ & $\frac{10,0 \pm 6,0}{<3,0-22,0}$ \\
\hline $\begin{array}{l}\text { Аея, } \\
n=14\end{array}$ & $\frac{7,01 \pm 0,32}{6,31-7,37}$ & $\frac{34,8 \pm 7,1}{24,1-48,5}$ & $\frac{18 \pm 8}{<5-34}$ & $\frac{7,8 \pm 3,2}{3,4-12,1}$ & $\frac{40 \pm 20}{14-70}$ & $\frac{7,2 \pm 3,8}{<3,0-15,6}$ \\
\hline $\begin{array}{l}\text { Бомышая } \\
\text { Бушунга }\end{array}$ & 7,21 & 54,6 & 13 & 4,6 & 37 & 3,2 \\
\hline $\begin{array}{l}\text { Малая } \\
\text { Бушунга }\end{array}$ & 7,06 & 58,6 & 12 & 5,6 & 22 & 9,6 \\
\hline $\begin{array}{l}\text { Большая } \\
\text { Желунда }\end{array}$ & 7,38 & 56,4 & 14 & 6,6 & 26 & 19,2 \\
\hline $\begin{array}{l}\text { Малая } \\
\text { Желунда }\end{array}$ & 7,42 & 51,6 & 16 & 5,6 & 14 & 11,8 \\
\hline
\end{tabular}

Примечание: в числителе - среАнее и среАнеквадратичное откмонение, в знаменателе минимацьное и максимацьное значения, $n$ - число проб. 
Преобладание миграции во взвеси характерно в большей степени Аля $\mathrm{Al}$, $\mathrm{Mn}, \mathrm{Fe}, \mathrm{Pb}$. В растворенной форме преАпочтительнее мигрируют $\mathrm{Cu}, \mathrm{Zn}, \mathrm{Cd}$ и Cr, что обусловлено образованием комплексов с органическими соеАинениями и стабилизацией их за счет этого в водной фазе. Металмы первой группы, кроме $\mathrm{Mn}$, также активно связываются в комплексы, причем степень их связывания меняется посезонно, что вызвано изменениями в составе растворенных органических веществ (РОВ) [11].

В водотоках с высоким содержанием РОВ Al преимущественно находится в составе комплексных соединений. В исследуемых малых реках его содержание в сравнении с кмарковым значением Аля речных воА $\left(50 \mathrm{Mкг} / \mathrm{AM}^{3}\right)[9,10]$ Аостаточно низкое, варьирует в широких преАелах $($ табл. 2,4$)$. Максимальные концентрации отмечаются в половодье и павоАки (рис. 2), когАа возрастает сток органических и взвешенных веществ. По уровню содержания повышенные значения характерны Аля воА рек Синель и Аея, Аренирующих в верхней части водосборов осадочные породы.

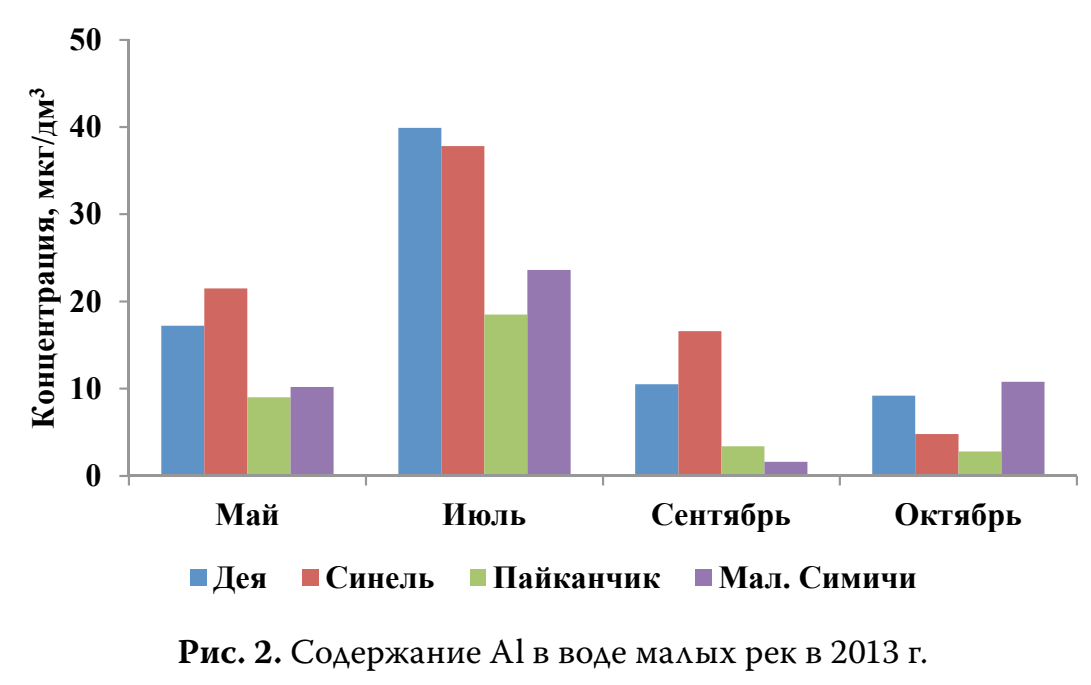

В реках Большие и Малые Симичи и Пайканчик, Аренирующих интрузивные и эффузивные породы, содержание $\mathrm{Al}$ значительно ниже. В р. Бурея с нейтральными значениями $\mathrm{pH}$ и более высоким содержанием РОВ концентрации $\mathrm{Al}$ на порядок выше (табл. 3) и возрастают в 1,7-2,0 раза от весны к осени при оАновременном увеличении содержания РОВ. В многовоАном 2013 г. при большом количестве атмосферных осаАков и увеличении сбросов Бурейской ГЭС максимальные концентрации отмечались в июле и сентябре при повышенных содержаниях РОВ и взвешенных веществ, цвет- 
Таблица 2. Содержание растворенных форм микроэлементов в воде правобережных притоков Нижне-Бурейского водохранилища, мкг/Ам ${ }^{3}$

\begin{tabular}{|c|c|c|c|c|c|}
\hline \multirow[b]{2}{*}{ Элемент } & \multicolumn{5}{|c|}{ Название притока, число проб } \\
\hline & $\begin{array}{c}\text { Синемь, } \\
n=14\end{array}$ & $\begin{array}{c}\text { Бомьшие } \\
\text { Симичи, } n=14\end{array}$ & $\begin{array}{c}\text { Мамые } \\
\text { Симичи, } n=13\end{array}$ & $\begin{array}{c}\text { Пайканчик, } \\
n=14\end{array}$ & Аея, $n=14$ \\
\hline \multirow{2}{*}{$\mathrm{Al}$} & $\underline{17,08 \pm 11,62}$ & $7,23 \pm 10,17$ & $\underline{8,20 \pm 6,68}$ & $\underline{6,56 \pm 4,96}$ & $17,41 \pm 10.40$ \\
\hline & $2,05-37,8$ & $\overline{1,97-41,6}$ & $1,6-23,6$ & $\overline{1,60-18,5}$ & $6,41-39.9$ \\
\hline \multirow{2}{*}{$\mathrm{Fe}$} & $\underline{280 \pm 260}$ & $\underline{220 \pm 210}$ & $\underline{270 \pm 230}$ & $\underline{540 \pm 1190}$ & $\underline{240 \pm 210}$ \\
\hline & $\overline{60-570}$ & $\overline{50-610}$ & $\overline{100-870}$ & $\overline{60-4600}$ & $50-640$ \\
\hline \multirow{2}{*}{$\mathrm{Mn}$} & $36,24 \pm 42.98$ & $\mathbf{7 6 , 5 6 \pm 1 3 , 1 5}$ & $\underline{\mathbf{1 3 8}, \mathbf{4} \pm 143,6}$ & $\underline{145,9 \pm 127,0}$ & $\underline{\mathbf{1 3}, \mathbf{9} \pm 13,8}$ \\
\hline & $0,34-131,1$ & $0,86-221,1$ & $0,73-532,0$ & $0,82-426,3$ & $0,55-39,67$ \\
\hline \multirow{2}{*}{$\mathrm{Ba}$} & $\underline{8,33 \pm 3,26}$ & $12,32 \pm 4,94$ & $\underline{83,35 \pm 205}$ & $\underline{11,09 \pm 4,04}$ & $\underline{7,39 \pm 4,08}$ \\
\hline & $3,78-12,50$ & $6,46-19,57$ & $13,02-765$ & $\overline{6,10-17,02}$ & $3,48-17,86$ \\
\hline \multirow{2}{*}{$\mathrm{Zn}$} & $20,24 \pm 12,50$ & $\underline{\mathbf{2 0}, \mathbf{4 7} \pm 17,13}$ & $\underline{15,92 \pm 9,56}$ & $\underline{14,23 \pm 8,42}$ & $\underline{\mathbf{1 8}, \mathbf{4 0} \pm 10,68}$ \\
\hline & $1,96-41,77$ & $0,57-59,3$ & $3,25-36,0$ & $2,50-26,90$ & $1,81-32,79$ \\
\hline \multirow{2}{*}{$\mathrm{Cu}$} & $\underline{4,69 \pm 6,42}$ & $\underline{\mathbf{6}, 28 \pm 10,06}$ & $\underline{4,73 \pm 5,93}$ & $\underline{\mathbf{4}, \mathbf{4 0} \pm 6,25}$ & $\underline{\mathbf{4}, \mathbf{8 0} \pm 2,87}$ \\
\hline & $\overline{0,43-24,4}$ & $0,10-38,6$ & $\overline{0,35-20,8}$ & $\overline{0,50-24,2}$ & $\overline{0,50-15,2}$ \\
\hline \multirow{2}{*}{$\mathrm{Hg}$} & $\underline{\mathbf{0 , 0 3} \pm 0,03}$ & $\underline{\mathbf{0}, 02 \pm 0,02}$ & $\underline{\mathbf{0 , 0 4} \pm 0,05}$ & $\underline{\mathbf{0}, \mathbf{0 2} \pm 0,02}$ & $\underline{\mathbf{0}, \mathbf{0 3} \pm 0,03}$ \\
\hline & $<0,01-0,13$ & $<0,01-0,06$ & $<0,01-0,16$ & $<0,01-0,06$ & $<0,01-0,11$ \\
\hline \multirow{2}{*}{$\mathrm{Cd}$} & $\underline{0,48 \pm 1,09}$ & $\underline{0,22 \pm 0,44}$ & $\underline{0,05 \pm 0,03}$ & $\underline{0,08 \pm 0,06}$ & $\underline{0,08 \pm 0,08}$ \\
\hline & $\overline{0,01-3,34}$ & $\overline{0,02-1,68}$ & & & $-0,16$ \\
\hline \multirow{2}{*}{$\mathrm{Co}$} & $\underline{0,14 \pm 0,09}$ & $\underline{0,13 \pm 0,08}$ & $\underline{0,22 \pm 0,18}$ & $\underline{0,20 \pm 0,19}$ & $0,04 \pm 0,02$ \\
\hline & $0,05-0,29$ & $0,05-0,27$ & $0,05-0,54$ & $0,05-0,62$ & $0,04-0,13$ \\
\hline \multirow{2}{*}{$\mathrm{Ni}$} & $\underline{1,16 \pm 0,45}$ & $\underline{1,03 \pm 0,49}$ & $\underline{1,37 \pm 0,51}$ & $\underline{0,98 \pm 0,37}$ & $\underline{0,94 \pm 0,45}$ \\
\hline & $\overline{0,61-1,98}$ & $\overline{0,52-2,10}$ & & & $0,31-1,83$ \\
\hline \multirow{2}{*}{$\mathrm{Pb}$} & $\underline{0,28 \pm 0,22}$ & $\underline{0,74 \pm 1,18}$ & $\underline{0,22 \pm 0,18}$ & $\underline{0,14 \pm 0,09}$ & $\underline{0,88 \pm 1,58}$ \\
\hline & $\overline{0,11-0,71}$ & $\overline{0,10-3,34}$ & $0,05-0,55$ & $0,06-0,32$ & $\overline{0,11-4,08}$ \\
\hline \multirow{2}{*}{ As } & $\underline{0,32 \pm 0,09}$ & $\underline{0,33 \pm 0,07}$ & $\underline{0,29 \pm 0,08}$ & $\underline{0,25 \pm 0,18}$ & $\underline{0,33 \pm 0,14}$ \\
\hline & $\overline{0,21-0,46}$ & $\overline{0,23-0,43}$ & $\overline{0,23-0,44}$ & $\overline{0,14-0,60}$ & $\overline{0,19-0,56}$ \\
\hline \multirow{2}{*}{$\mathrm{Cr}$} & $\underline{0,10 \pm 0,05}$ & $\leq 0,10$ & $\leq 0,10$ & $\leq 0,10$ & $\underline{0,04 \pm 0,13}$ \\
\hline & $0,06-0,13$ & $<0, \overline{10-0,26}$ & $<0, \overline{10-0,34}$ & $<0,10-0,12$ & $0,07-0,25$ \\
\hline $\mathrm{Be}$ & $\frac{0,02}{0,01-0,02}$ & 0,01 & 0 & $\frac{0,02}{0,01-0,02}$ & $\frac{0,02}{0,01-0,02}$ \\
\hline \multirow{2}{*}{ B } & $\underline{1,17 \pm 1,95}$ & $\underline{2,01 \pm 2,27}$ & $\underline{4,42 \pm 6,40}$ & $\underline{1,72 \pm 2,42}$ & $\underline{2,30 \pm 2,68}$ \\
\hline & 0,04 & $0,40-5,95$ & $0,84-15,77$ & 5,26 & $0,55-6,86$ \\
\hline \multirow{2}{*}{ Mo } & $\underline{0,19 \pm 0,09}$ & $\underline{0,25 \pm 0,18}$ & $\underline{0,21 \pm 0,11}$ & $\underline{0,15 \pm 0,08}$ & $\underline{0,25 \pm 0,18}$ \\
\hline & $0,09-0,36$ & $0,11-0,72$ & $0,10-0,43$ & $0,04-0,28$ & $0,08-0,58$ \\
\hline \multirow{2}{*}{$\mathrm{Sb}$} & $\underline{0,03 \pm 0,02}$ & $\underline{0,05 \pm 0,06}$ & $\underline{0,05 \pm 0,03}$ & $\underline{0,03 \pm 0,01}$ & $\underline{0,05 \pm 0,02}$ \\
\hline & & & & & $\overline{0,03-0,07}$ \\
\hline \multirow{2}{*}{ Se } & $\underline{0,09 \pm 0,05}$ & $\underline{0,08 \pm 0,05}$ & $\underline{0,13 \pm 0,06}$ & $\underline{0,08 \pm 0,05}$ & $\underline{0,10 \pm 0,06}$ \\
\hline & & $\overline{0,02-0,14}$ & $\overline{0,04-0,22}$ & $0,03-0,15$ & $\overline{0,01-0,16}$ \\
\hline \multirow{2}{*}{ V } & $\underline{0,06 \pm 0,03}$ & $\underline{0,04 \pm 0,02}$ & $\underline{0,07 \pm 0,07}$ & $\underline{0,04 \pm 0,02}$ & $\underline{0,08 \pm 0,05}$ \\
\hline & $\overline{0,03-0,10}$ & $\overline{0,03-0,07}$ & $\overline{0,02-0,17}$ & $\overline{0,03-0,08}$ & $0,05-0,17$ \\
\hline
\end{tabular}

Примечание: жирным шрифтом выделены случаи превышения ПАК; в числителе - среАнее и среАнеквадратичное откмонение, в знаменателе - минимацьное и максимацьное значения, $n$ - число проб. 
ности воды. По Алине р. Бурея незначительное превышение среАних концентраций $\mathrm{Al}$ наблюдается выше плотины Нижне-Бурейской ГЭС. Такое же распределение характерно Аля $\mathrm{Fe}, \mathrm{Zn}, \mathrm{Cu}, \mathrm{Ni}$. Повышенные концентрации метальов, очевиАно, обусловлены преобразованиями на водосборе, которые способствуют повышению роли тонкодисперсного вещества в растворенной фракции микроэлементов за счет миграции в условно растворенной форме (фильтрат 0,45 мкм) [3].

Цинк в воде рек мигрирует в ионной форме или в форме его минеральных и органических комплексов. В воде рек бассейна р. Уссури до $20 \%$ $\mathrm{Zn}$ мигрирует в тонкодисперсной или крупно-колмоиАной форме $(0,1-$ 0,45 мкм), что может несколько завышать содержание истинно растворенных форм [4]. В притоках Нижне-Бурейского водохранилища среАние концентрации варьировали в узких преАелах: 14,2-26,3 мкг/Ам ${ }^{3}$ (табл. 2-4). Тренд сезонных изменений в р. Бурея и малых реках был одинаков. В 2011-2012 гг. содержание Zn повышалось в октябре-ноябре. В 2013 г. максимальные концентрации отмечались в июле в паводок, в 2014 г. в мае во время половодья. Таким образом, характер сезонной изменчивости растворенных форм $\mathrm{Zn}$ в реках разнообразен и опреАелялся комбинацией контролирующих факторов.

Марганец в отличие от Аругих метал ов менее всего связывается в комплексы. Содержание его в воде определяется интенсивностью потребления при фотосинтезе, разможением водорослей и высшей водной растительности, процессами осаждения на Ано и Ар. В воде исследуемых рек содержание Mn изменялось в широких пределах. Максимальные и высокие значения среАних концентраций отмечены в воде рек Малые Симичи и Пайканчик, Аренирующих преимущественно эффузивные породы. Временные колебания содержания в них определялись, в основном, соотношением поверхностного и подземного стока, обусловливающих значительное увеличение концентрации Mn осенью. В реках Аея и Синель среАнее содержание $\mathrm{Mn}$ было значительно ниже, хотя сезонная Аинамика сохранялась. Концентрации $\mathrm{Mn}$ в воде р. Бурея сопоставимы со значениями Аля рек Аея и Синель. По Алине реки от пос. Талакан Ао пос. Новобурейский содержание Мn снижается, что может быть связано с его перераспределением между растворенной и взвешенной формами при изменении параметров среАы, а также за счет потребления водорослями.

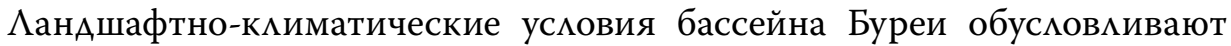
появление обширных заболоченных территорий, определяющих образование Fе-органических комплексов. Сезонные изменения содержания железа связаны с вариациями гидрологического режима. Повышение концентраций отмечалось Аетом и осенью за счет поступления с водосбора в 
Табцица 3. Содержание растворенных форм микроэлементов в воде р. Бурея, мкг/Ам ${ }^{3}$

\begin{tabular}{|c|c|c|c|}
\hline \multirow[b]{2}{*}{ Э^емент } & \multicolumn{3}{|c|}{ Название притока, число проб } \\
\hline & пос. Тамакан, $n=14$ & $\begin{array}{c}\text { Выше Нижне- } \\
\text { Бурейской ГЭС, } n=36\end{array}$ & $\begin{array}{c}\text { Ниже Нижне- } \\
\text { Бурейской ГЭС, } n=14\end{array}$ \\
\hline \multirow{2}{*}{$\mathrm{Al}$} & $93,03 \pm 44,42$ & $\underline{102,38 \pm 51,61}$ & $\underline{\mathbf{8 4}, 53 \pm 51,86}$ \\
\hline & $39,88-210,8$ & $34,71-241,0$ & $33,53-153,9$ \\
\hline \multirow{2}{*}{$\mathrm{Fe}$} & $\underline{200,0 \pm 110,0}$ & $\underline{\mathbf{2 2 0}, 0 \pm 120,0}$ & $\underline{190,0 \pm 110,0}$ \\
\hline & $\begin{array}{c}90-390 \\
\mathbf{4 4 , 1 5} \pm 21,61\end{array}$ & $\begin{array}{c}90,0-490,0 \\
15,23 \pm 15,26\end{array}$ & $\begin{array}{c}90-430,0 \\
13.65+14.88\end{array}$ \\
\hline Mn & $\frac{11,10-21,01}{13,86-97,42}$ & $\frac{10,201,1,60}{1,04-61,66}$ & $\frac{10,0011,00}{1,11-56,41}$ \\
\hline $\mathrm{Ba}$ & $\frac{7,57 \pm 2,45}{4,27-11,1}$ & $\frac{6,60 \pm 2,56}{1,70-10,99}$ & $\frac{6,93 \pm 2,21}{4,02-11,57}$ \\
\hline \multirow{2}{*}{$\mathrm{Zn}$} & $\underline{22,04 \pm 12,40}$ & $\underline{\mathbf{2 6}, 29 \pm 12,42}$ & $\underline{18,07 \pm 11,24}$ \\
\hline & $\begin{array}{l}6,93-49,5 \\
\underline{\mathbf{5}, 08 \pm 7,58} \\
\end{array}$ & $\begin{array}{l}3,53-97,6 \\
\underline{\mathbf{8}, 05} \pm 9,73 \\
\end{array}$ & $\begin{array}{c}0,10-42,43 \\
\mathbf{5 , 1 2} \pm 5,82\end{array}$ \\
\hline $\mathrm{Cu}$ & $\overline{0,50-29,9}$ & $\overline{0,33-41,2}$ & $\overline{0,43-22,1}$ \\
\hline $\mathrm{Hg}$ & $\frac{\mathbf{0 , 0 2} \pm 0,03}{<0,01-0,11}$ & $\frac{\mathbf{0 , 0 3} \pm 0,04}{<0,01-0,22}$ & $\frac{\mathbf{0 , 0 2} \pm 0,03}{<0,01-0,09}$ \\
\hline \multirow{2}{*}{$\mathrm{Cd}$} & $\underline{0,05 \pm 0,04}$ & $\underline{0,04 \pm 0,02}$ & $\underline{0,08 \pm 0,08}$ \\
\hline & $0,01-0,12$ & $0,02-0,09$ & $0,02-0,14$ \\
\hline Co & $\frac{0,04 \pm 0,02}{0,02-0,06}$ & $\frac{0,03 \pm 0,01}{0,02-0,05}$ & $\frac{0,03 \pm 0,006}{0,02-0,04}$ \\
\hline \multirow{2}{*}{$\mathrm{Ni}$} & $\underline{0,72 \pm 0,22}$ & $\underline{0,89 \pm 0,38}$ & $\underline{0,71 \pm 0,29}$ \\
\hline & $\begin{array}{l}0,44-1,13 \\
\underline{0,37 \pm 0,36}\end{array}$ & $\begin{array}{l}0,45-1,60 \\
\underline{0,26 \pm 0,16}\end{array}$ & $\begin{array}{l}0,48-1,48 \\
0,37 \pm 0,37 \\
\end{array}$ \\
\hline $\mathrm{Pb}$ & $0,04-0,91$ & $\overline{0,04-0,53}$ & $\overline{0,09-0,90}$ \\
\hline \multirow{2}{*}{ As } & $\underline{0,30 \pm 0,06}$ & $\underline{0,32 \pm 0,07}$ & $\underline{0,31 \pm 0,05}$ \\
\hline & $\begin{array}{l}0,21-0,37 \\
0,04 \pm 0,02 \\
\end{array}$ & $\begin{array}{l}0,23-0,45 \\
0,22 \pm 0,09 \\
\end{array}$ & $\begin{array}{l}0,23-0,36 \\
0,08 \pm 0,08 \\
\end{array}$ \\
\hline $\mathrm{Cr}$ & $\overline{0,02-0,06}$ & $0,14-0,37$ & $0,03-0,19$ \\
\hline \multirow{2}{*}{$\mathrm{Be}$} & $\underline{0,02 \pm 0,01}$ & $\underline{0,03 \pm 0,006}$ & $\underline{0,02 \pm 0,01}$ \\
\hline & $0,01-0,03$ & $0,01-0,03$ & $\overline{0,01-0,03}$ \\
\hline \multirow{2}{*}{ B } & $\underline{1,41 \pm 1,48}$ & $\underline{3,28 \pm 2,27}$ & $\underline{2,81 \pm 1,87}$ \\
\hline & $\overline{0,17-3,87}$ & $\overline{1,23-7,44}$ & $\overline{1,04-5,61}$ \\
\hline \multirow{2}{*}{ Mo } & $\underline{0,18 \pm 0,05}$ & $\underline{0,28 \pm 0,17}$ & $\underline{0,26 \pm 0,18}$ \\
\hline & $0,11-0,27$ & $0,14-0,91$ & $0,13-0,73$ \\
\hline \multirow{2}{*}{$\mathrm{Sb}$} & $\underline{0,08 \pm 0,07}$ & $\underline{0,06 \pm 0,03}$ & $\underline{0,06 \pm 0,02}$ \\
\hline & $\overline{0,02-0,21}$ & $\overline{0,01-0,10}$ & $\overline{0,03-0,09}$ \\
\hline \multirow{2}{*}{$\mathrm{Se}$} & $\underline{0,10 \pm 0,07}$ & $\underline{0,16 \pm 0,11}$ & $\underline{0,08 \pm 0,06}$ \\
\hline & $0,02-0,19$ & $0,03-0,35$ & $\overline{0,02-0,24}$ \\
\hline \multirow{2}{*}{ V } & $\underline{0,06 \pm 0,02}$ & $\underline{0,07 \pm 0,04}$ & $\underline{0,06 \pm 0,02}$ \\
\hline & $0,03-0,08$ & $0,05-0,18$ & $0,01-0,07$ \\
\hline
\end{tabular}

Примечание: жирным шрифтом выделены случаи превышения ПАК; в числителе - среАнее и среАнеквадратичное откцонение, в знаменателе - минимальное и максимацьное значения, $n$ - число проб. 
Таблица 4. Содержание растворенных форм микроэлементов в воде мевобережных притоков Нижне-Бурейского водохранилища, мкг/Ам ${ }^{3}$

\begin{tabular}{c|c|c|c|c}
\hline \multirow{2}{*}{ Элемент } & \multicolumn{4}{|c}{ Название притока } \\
\cline { 2 - 5 } & $\begin{array}{c}\text { Большая } \\
\text { Бушунга }\end{array}$ & $\begin{array}{c}\text { Малая } \\
\text { Бушунга }\end{array}$ & $\begin{array}{c}\text { Большая } \\
\text { Желунда }\end{array}$ & $\begin{array}{c}\text { Малая } \\
\text { Желунда }\end{array}$ \\
\hline $\mathrm{Al}$ & 27,15 & 13,09 & 22,88 & 38,09 \\
$\mathrm{Fe}$ & $\mathbf{2 5 0 , 0}$ & 90,0 & $\mathbf{1 4 0 , 0}$ & 60,0 \\
$\mathrm{Mn}$ & $\mathbf{1 3 , 9 8}$ & $\mathbf{3 2 , 2 7}$ & 1,09 & 0,73 \\
$\mathrm{Ba}$ & 6,66 & 7,50 & 8,91 & 11,43 \\
$\mathrm{Zn}$ & 5,68 & 6,39 & 3,78 & $\mathbf{1 0 , 6 5}$ \\
$\mathrm{Cu}$ & 0,81 & $\mathbf{1 , 5 1}$ & $\mathbf{1 , 7 6}$ & $\mathbf{7 , 6 4}$ \\
$\mathrm{Hg}$ & $\mathbf{0 , 0 5}$ & 0,01 & $\mathbf{0 , 0 2}$ & 0,01 \\
$\mathrm{Cd}$ & 0,02 & 0,02 & 0,02 & 0,02 \\
$\mathrm{Co}$ & 0,05 & 0,07 & 0,03 & 0,03 \\
$\mathrm{Ni}$ & 0,72 & 0,86 & 0,57 & 0,54 \\
$\mathrm{~Pb}$ & 0,08 & 0,06 & 0,09 & 0,24 \\
$\mathrm{As}$ & 0,17 & 0,15 & 0,12 & 0,09 \\
$\mathrm{Cr}$ & $<0,10$ & $<0,10$ & $<0,10$ & $<0,10$ \\
$\mathrm{Be}$ & 0,01 & 0,01 & 0,01 & 0,01 \\
$\mathrm{~B}$ & 0,37 & 0,44 & 0,03 & 0,03 \\
$\mathrm{Mo}$ & 0,21 & 0,15 & 0,39 & 0,16 \\
$\mathrm{Sb}$ & 0,04 & 0,05 & 0,04 & 0,03 \\
$\mathrm{Se}$ & 0,13 & 0,12 & 0,12 & 0,24 \\
$\mathrm{~V}$ & 0,05 & 0,04 & 0,04 & 0,03 \\
\hline
\end{tabular}

Примечание: жирным шрифтом выделены скучаи превышения ПАК.

период интенсивных дождей. Максимахьные за периоА наблюдений значения отмечались в малых реках в июле 2011 г. В воде р. Пайканчик концентрация Fе Аостигала 4,60 мг/Ам ${ }^{3}$ при высоких значениях цветности (260 граАусов цветности) и ХПК (44 мг О/Ам $\left.{ }^{3}\right)$. Повышенным было и содержание $\mathrm{Mn}$ $\left(426,3\right.$ мкг/Ам $\left.{ }^{3}\right)$ как наиболее подвижного элемента по отношению к железу. Увеличение содержания взвешенных веществ Ао $22 \mathrm{mг} / \mathrm{Am}^{3}$, вероятно, определило возрастание роли тонкодисперсного вещества в растворенной фракции. В воде р. Буреи среАние концентрации Fе и максимальные значения пределов колебания были ниже, чем в малых реках.

Аиапазон среАних концентраций $\mathrm{Pb}$ в воде исследуемых рек (табл. 2-4) находится в пределах среАних значений Аля рек мира $\left(1\right.$ мкг/Ам $\left.{ }^{3}\right)$ [10]. Повышенное содержание характерно Аля воды рек Большие Симичи и Аея, на водосборах которых отмечаются проявления золота, серебра, молибАена 
и Аругих метациов [8]. В этих же водотоках отмечацись максимацьные за период наблюдений концентрации $\mathrm{Pb}$ (3,34 и 4,08 мкг/Ам ${ }^{3}$ соответственно) в мае 2014 г. на фоне незначительного повышения содержания взвешенных веществ. В остальных махых реках концентрации были на порядок ниже.

СреАние концентрации $\mathrm{Cu}$ в р. Бурея и малых реках были оАного порядка и превышахи ПАК (1,00 мкг/ Ам$\left.^{3}\right)$ (табл. 2-4). Аля сезонной изменчивости характерна большая вариабельность значений от Аесятых Аолей Ао Аесятков мкг/Ам ${ }^{3}$. МеАь образует прочные комплексы со многими органическими веществами (OB), причем устойчивость их значительно выше устойчивости комплексов Аругих метацлов. Транспорт и мобимизация органических комплексов меАи, главным образом фульватных, усимиваются в павоАки и половодье. Поэтому максимахьные концентрации $(15,2-$ 38,6 мкг/Ам ${ }^{3}$ ) в малых реках и до 41,2 мкг/Ам ${ }^{3}$ в р. Бурее наблюАались в периоА интенсивных АожАей в 2013 г., обусловивших увеличение содержания POB, цветности воды и вынос метац ов, мобимизуемых из почв и растительности (рис. 3). Повышенные концентрации Сu отмечены весной 2013 и 2014 гг. Концентрации Сr изменялись в небольших преАелах, среАние значения состав яли десятые и сотые Аоли мкг/Ам ${ }^{3}$.

Среднее содержание Ва Аля рек мира составцяет 20 мкг/Ам ${ }^{3}$ [10]. В притоках Нижне-Бурейского водохранимища, за искмючением р. Малые Симичи, концентрации значительно ниже. Повышенный сток отмечался в паводки 2013 г. и осеннюю межень 2012 г. Концентрации Ва в воде р. Махые Симичи (табл. 2) на фоне остальных рек значительно выше, что может быть вызвано разгрузкой подземных вод артезианских бассейнов. Большое распространение содержащие барий подземные воды имеют в СреАнеамурском, Верхнебуреинском и Аругих межгорных артезианских бассейнах, в послеАнем концентрация этого элемента Аостигает 0,4 мг/Ам ${ }^{3}$ [12].

КаАмий в воде притоков Нижне-Бурейского водохранимища, за искмючением рек Синель и Большие Симичи, составмяет сотые, реже Аесятые Аоли мкг/AM ${ }^{3}$, что соответствует среАнему значению Аля рек мира $[9,10]$ (табл. 2-4). Средние концентрации Сd в реках Синель и Большие Симичи на порядок выше за счет разовых повышенных значений $\left(3,34\right.$ и 1,68 мкг/Aм ${ }^{3}$ соответственно) в многоводном 2013 г.

Аля содержания $\mathrm{Ni}$ характерно относительно равномерное распреАеление. Средние концентрации варьируют в предеках 1 мкг/Ам ${ }^{3}$ : 0,941,37 мкг/Ам ${ }^{3}$ в малых реках и 0,71-0,89 мкг/Ам ${ }^{3}$ в р. Бурее. Аля сезонного распределения характерны незначительные колебания с повышением соАержания в половодье и паводки.

Кобальт в воде рек обнаруживается реже, чем $\mathrm{Ni}$, что можно объяснить его меньшей миграционной способностью и низким содержанием в горных породах [13]. Концентрации Со в воде мамых рек и р. Бурее состав яли со- 
a

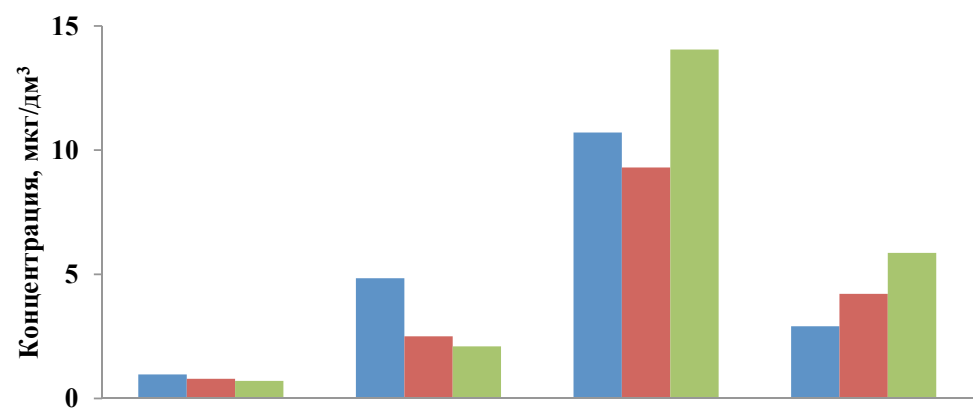

6

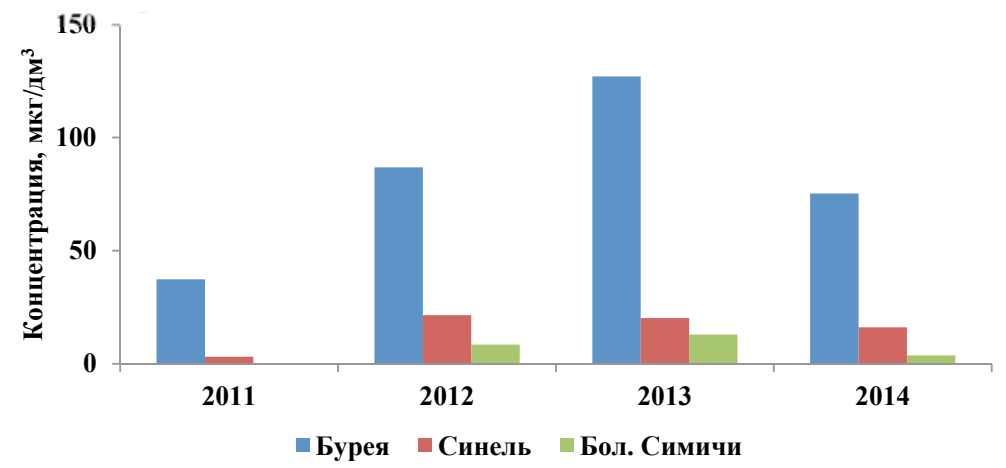

Рис. 3. Изменение среАних концентраций $\mathrm{Cu}(\mathrm{a})$ и $\mathrm{Al}$ (б) в водах притоков Нижне-Бурейского водохранимища.

тые Аоли мкг/АM ${ }^{3}$, возрастая иногАа Ао десятых Аолей в осеннюю межень в октябре-ноябре. Повышенные значения характерны Аля рек Малые Симичи и Пайканчик (табл. 2).

Содержание As в водах притоков низкое, ниже среАнего значения Аля рек мира (2,0 мкг/Ам $\left.{ }^{3}\right)$ [10]. Невысокие концентрации $\left(0,30-0,32\right.$ мкг/AM ${ }^{3}$ средние значения) с узким интервалом колебания (0,21-0,45 мкг/Ам $\left.{ }^{3}\right)$ характерны Аля воды р. Буреи и махых рек бассейна $\left(0,25-0,33\right.$ мкг/Ам ${ }^{3}$ среАние значения с интерва ом 0,14-0,60 мкг/Aм $\left.{ }^{3}\right)$. Незначитемьное повышение содержания As отмечалось в мае и июле.

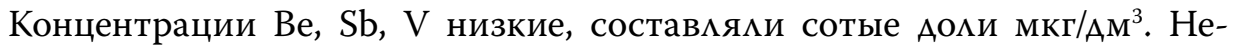
сколько выше, Ао Аесятых Аолей мкг/Ам ${ }^{3}$, содержание Se. Небольшое сезонное повышение концентраций отмечалось в весеннее половодье и осенью. Концентрации Мо составляли Аесятые Аоли мкг/Ам ${ }^{3}$, среАние значения быми сопоставимы с содержанием в таежных реках бассейна р. Амур [4].

Бор в природных водах в виде ионов борных кислот присутствует повсеместно в незначительных количествах [13]. Щелочные воды более бога- 
ты В, чем жесткие, что связано с кучшей растворимостью натриевых солей борных кислот по сравнению с кальциевыми и магниевыми. В воде исслеАованных рек содержание В изменялось в узком интервале. Наибольшие значения наблюАахись в воде р. Малые Симичи с повышенными по сравнению с остальными притоками вецичиной $\mathrm{pH}$ и содержанием иона натрия [2]. Аля сезонного изменения характерно увекичение весной.

Ртуть характеризуется высокой интенсивностью вовцечения в водную миграцию, активно поглощается водорослями, Аегко сорбируется почвами, образуя комплексы с гумусовыми кислотами (ГК), сорбционная емкость которых по отношению к ионам Hg (II) весьма высока [14]. Во многих воАотоках $\mathrm{Hg}$ в виле киновари встречается в современных речных отложениях (шиихах), особенно в местах распространения россыпей золота и его шлиховых ореолов [15]. СреАние концентрации Нg в бассейне р. Буреи в 24 раза превыша и значение ПАК $\left(0,01\right.$ мкг/Ам $\left.{ }^{3}\right)$ в воде притоков и в 2-3 раза в основной реке. Превышение ПАК отмечацось в $43 \%$ проб воды малых рек и 62 \% р. Буреи. Оценка среАних кваАратичных отклонений свидетельствует о значительном рассеянии концентраций вокруг среАних значений. Аля

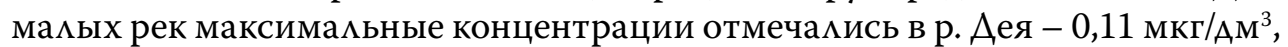
Синель - 0,13 мкг/Ам ${ }^{3}$, Аренирующих осадочные породы, и в р. Малые Симичи - 0,16 мкг/Ам ${ }^{3}$. Максимахьная за период наблюдений концентрация Hg в воде р. Буреи $\left(0,22\right.$ мкг/Ам $\left.{ }^{3}\right)$ наблюдалась в мае 2014 г. у пос. Та акан. Исследования, выполненные на Курейском водохранилище, показали, что при его наполнении $\mathrm{Hg}$ аккумулируется в поверхностном гумусовом слое затопленных почв, в формирующихся Аонных отложениях и мышцах рыб [16]. Аналогичная ситуация наблюдалась при наполнении канадских водохранимищ, снижение концентраций $\mathrm{Hg}$ в мышцах рыб зарегистрировано в водохранимищах, возраст которых составля 35 и более мет [17].

ВАияние гиАрологической обстановки на водосборе прояв ялось в увемичении (Ао 75 \%) количества проб, превышающих ПАК, в условиях низкой водности в р. Бурее. Повышенные концентрации Нg в условиях низкой воАности в июне 2012 г. отмечались во всех водотоках (за искиючением р. Пайканчик). В многоводном 2013 г. содержание Нg, в основном, было ниже 0,01 мкг/AM ${ }^{3}$, в засушливом 2014 г. концентрации Hg в малых реках незначительно превыша и значения ПАК.

Разовый отбор проб в 2014 г. на мевых притоках Нижне-Бурейского водохранимища свидетельствует о близости их химического состава с водами правых притоков: слабощелочная $\mathrm{pH}$, низкая (Ао 58 мг/Ам ${ }^{3}$ ) минерахизация воды (табл. 2, 4). Соподчиненное влияние зональных факторов формирования мево- и правобережных притоков определяет близость их химического состава и геохимической обстановки, в которой они формируются. Концентрации металмов в воде мевых и правых притоков в эти сроки от- 
бора сопоставимы. Незначительные размичия отмечаются Аля $\mathrm{Al}$ и $\mathrm{Mn}$. CoАержание $\mathrm{Al}$ в воде мевых притоков было выше, а $\mathrm{Mn}$ значительно ниже по сравнению с правыми притоками.

Как уже отмечалось, химический состав воА в бассейне в период исслеАований формировался при значительных колебаниях водного стока за счет больших размичий в количестве атмосферных осадков. В 2013 г. в бассейне Амура отмечалось историческое (впервые за 115 мет наблюдений) наводнение, обусловленное последовательным участием и наложением паводков на основных притоках (Зея, Бурея, Сунгари, Уссури). Гидрологический фактор в Аанных условиях оказал большое влияние на сток растворенных веществ. В условиях высокой водности в 2013 г. содержание $\mathrm{Cu}$ в р. Бурее и притоках было в 2,0-2,6 раза выше средних за период наблюдений значений, $\mathrm{Al}$ в $1,2-1,8$ раза, незначительное повышение содержания Fе отмечалось во всех притоках, $\mathrm{Cd}$ - только в реках Большие Симичи и Синель, Аля остальных металмов выраженного увеличения содержания не наблюдалось (рис. 3).

\section{ВЫВОАЫ}

Притоки Нижне-Бурейского водохранилища характеризуются значительными вариациями физико-химических характеристик: величины $\mathrm{pH}$, содержания взвешенных веществ, концентраций растворенных форм отАельных металмов. Содержание растворенных форм металмов в воде р. Буреи и ее притоках, в основном, невысокое и сопоставимо со среАнемировыми значениями в речных водах. Искмючение составляют концентрации Fе, $\mathrm{Mn}, \mathrm{Cu}, \mathrm{Hg}$, которые зачастую превышают значения ПАК В отсутствии интенсивной антропогенной нагрузки их повышенное содержание, очевидно, соответствует естественному геохимическому фону территории, указывает на значительную роль заболоченных таежных мандшафтов и подземной состав яющей в питании отАельных рек, возрастающей в условиях низкой воАности. Характер сезонной изменчивости растворенных форм металмов разнообразен, в большой степени определяется гиАрологическим фактором.

\section{СПИСОК АИТЕРАТУРЫ}

1. Мордовин А.М., Шестеркин В.П., Антонов А.А. Река Бурея: гиАрология, гиАрохимия, ихтиофауна. Хабаровск: ИВЭП АВО РАН, 2006. 146 с.

2. Шестеркин В.П., Сиротский С.Е., Таловская В.С., Шестеркина Н.М., Форина Ю.А., Ри Т.А., Матвеева Е.П. ГиАрохимия притоков Нижне-Бурейского водохранилища // Научные основы экологического мониторинга водохраникищ. Мат-лы. всерос. науч.-практ. конф. Хабаровск, 2010. С. 176-179.

3. Шестеркин В.П., Сиротский С.Е., Шестеркина Н.М. Воздействие гиАроэнергетического строительства на содержание и сток растворенных веществ в воде реки Бурея // Водное хозяйство России. 2014. № 4. С. 72-83.

ВоАное хозяйство России № 3, 2016 г. 
4. Чудаева В.А., Шестеркин В.П., Чудаев О.В. Микроэлементы в поверхностных водах бассейна реки Амур // Водные ресурсы. 2011. № 5. С. 606-617.

5. Шестеркин В.П., Шестеркина Н.М. Микроэкементы в воде махых рек - притоков Нижне-Бурейского водохранилища // Современные проблемы водохранимищ и их водосборов. Тр. V межАунар. науч. конф. Т. 2. Пермь. 2015. С. 183-187.

6. Об утверждении нормативов качества воды водных объектов рыбохозяйственного значения. Приказ Росрыболовства от 18.01.2010 № 20.

7. Алекин О.А. Основы гидрохимии. А.: Гидрометеоиздат, 1970.440 с.

8. Петрук Н.Н., Волкова Ю.Р., Шилова М.Н., Мялик А.В., Шадрина Н.И., Азарова И.А. Государственная геологическая карта Российской Федерации. Масштаб 1:1 000000 (третье поколение). Серия Аахьневосточная. Аист М 52. Благовещенск. Объяснительная записка. СПб.: Картографическая фабрика ВСЕГЕИ, 2012. 496 с.

9. Аобровольский В.В. География микроэлементов. Гцобальное рассеяние. М.: Мысль, 1983. 272 с.

10. Hitchon B., Perkins E.N., Gunter W.D. Introduction to the Ground Water Geochemistry. Sherwood Rark; Alberta: Geoscience Publishing Ltd., 1999. 310 p.

11. Аинник П.Н., Набиванец Б.И. Формы миграции метациов в пресных поверхностных водах. А.: ГиАрометеоизАат, 1986. 270 с.

12. Кулаков В.В. Геохимия подземных воА Приамурья. Хабаровск: ИВЭП АВО PAH, 2011. 254 c.

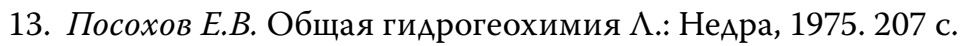

14. Варшал Г.М., Кощеева И.Я., Хушвахтова С. А., Холин Ю.В., Тютюник О.А. О механизме сорбции ртути (II) гуминовыми кислотами // Почвоведение. 1998. № 9. С. 1071-1078.

15. Буряк В.А., Рянский Ф.Н., Хмелевская Н.М. Геохимическая специализация как основа при меАико-биологическом и эколого-ланАшафтном районировании (на примере Азиатско-Тихоокеанского региона). БиробиАжан. 1998. 76 с.

16. Сороковикова А.М. Качество воды Саяно-Шушенского и Курейского водохранилищ в период наполнения // Научные основы экологического мониторинга водохранилищ. Мат-лы всерос. науч.-практ. конф. Хабаровск, 2010. С. 147-151.

17. Jackson T.A. The mercuru problem in recently from ed reservoirs of $\mathrm{N}$ orthem $\mathrm{M}$ anitoba (Canada): effects of impoundment and other factors on the productions of methyl mercury by microorganism in sediments // Can. J. Fich. Aquat. Sci., 1988. Vol. 45. P. 97-121.

\section{Сведения об авторах:}

Шестеркина Нина Михайловна, старший научный сотрудник, ФГБУН «Институт водных и экологических проблем Аальневосточного отАеления Российской акаАемии наук», Россия, 680000, Хабаровск, ум. Аикопомьцева, 56; e-mail: shesterkina@ ivep.as.khb.ru

Шестеркин Владимир Павлович, канА. геогр. наук, веАущий научный сотрудник, ФГБУН «Институт воАных и экологических проблем Аацьневосточного отАеления Российской академии наук», Россия, 680000, Хабаровск, ум. Аикопольцева, 56; e-mail: shesterkin@ivep.as.khb.ru 